\title{
Practical Exploration in Application Ability Training of Database Technology for College Students
}

\author{
Zhen Zhu, Fan-zhi Zeng \\ Foshan University, Foshan, China \\ augustjune@fosu.edu.cn
}

\begin{abstract}
With increasing popularity of computer application and constant extension of database application fields, In order to train application skills of database technology and improve their information consumption ability for college students, this paper establishes different training system of database application ability according to different train positioning for various classes of professional students. Practices in the ability cultivation of database application are presented, including multi-layers configuring knowledge points, progressive training of database application ability, and ability training by university-enterprise cooperation. Practice has proved that idea innovation and practice exploration are effective, and can greatly enhance students' application ability of database technology.
\end{abstract}

Index Terms - College students, Database application, Train positioning, Training system, University-enterprise cooperation

\section{Introduction}

With the development of computer technology and the popularization of computer application, database technology has extended to computer aided design, business management, e-government, decision-making support, information systems construction, and so on, from initial data storage, information management and transaction processing. In particular, such new technology emerged in recent years as data warehouse, data mining, business intelligence, big-data processing etc. make database technology application into a higher level, even popularization and application of cloud computing, Internet of things technology also need database technology as a foundation support. Therefore, database technology is a basic technology of computer application, which is also one of the key technologies of computer application.

In recent years, network has a great influence on people's work and life style, people no longer purely or excessively rely on traditional books, newspaper or interpersonal relationship network to obtain information, but more take such mobile terminals as hand-phone, PDA, notebook computer or desktop computer connected to Internet for getting information. So people's information consumption habit and information consumption space have had a great changes, network has become main channel to implement information consumption ${ }^{[1]}$. Whereas, network information collection, organization, storage, processing, transmission and presentation, from dynamic webpage, to blog, community, and forum, as well as various information systems, online resources and so on, all are implemented by the support of database technology. According to statistics, more than $70 \%$ software development tasks are related to the application of database technology.
Therefore, the education on computational thinking and information literacy for college students not only rest with basic computer operation skill training ${ }^{[2]}$, but also should lie in cultivating the application thinking of database technology, mastering database application skills adapted to their specialty. So the solid foundation may be laid for information collection, information storage, information processing, information transmission, and information innovation in their future study, work and life.

\section{Train Positioning and Training System}

\section{A. Train Positioning of Database Application Ability}

In 2006, Jeannette M. Wing proposed the concept of Computational Thinking which is generally accepted and advocated by international academic community ${ }^{[3]}$. So-called computational thinking is using basic concepts of computer science to solve problem, design system, and understand human behavior. The ways and methods, which computer science solves problem, should be used in other disciplines and people's daily life. The essence of computational thinking is abstract and automation; everybody should have this way of thinking. Like reading, writing, and arithmetic, computational thinking will become one of the most basic, common, applicable and fundamental way of thinking.

For college students, the application ability cultivation of database technology is an important part in the education of computational thinking and information literacy. According to different professionals of college students, in the light of their different employment direction, setting different cultivation objectives, establishing different teaching system and training system of database application course, so college students may build information organization and information processing thinking which can match with the information age, and they will become innovative talents with higher information consumption level.

In accordance with the train positioning of database application ability, all college students may be divided into three categories. Class A of college students not only has solid theoretical knowledge of database technology, but also should be able to do database modeling, and as well as information system design, development, management and maintenance etc. Class B of college students need perfect application thinking of database technology, not only master information collection, processing, and transmission techniques, but also should be able to perform database application modeling of business process, and participate in demand analysis and 
concept design of information system when necessary. Class $\mathrm{C}$ of college students only need to establish information organization thinking and information processing mode of database technology, understand current application situation and development trend of database technology. The train positioning of database application ability for college students is shown in Fig.1.

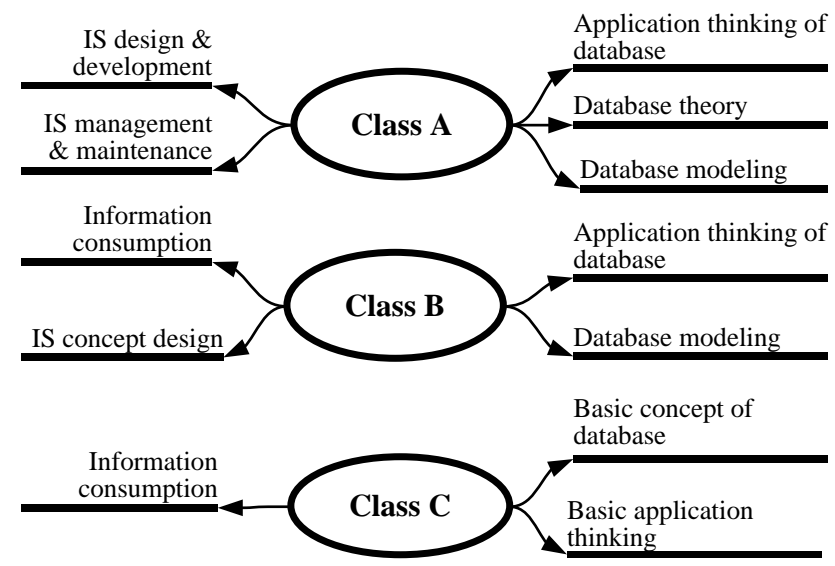

Fig.1 Train Positioning of Database Application Ability for College Students

Obviously, class A of college students is corresponding with computer professionals and their future jobs may be database designers, database administrators or information system developers. And class B of college students is corresponding with non-computer professionals, but they may be often engaged in a large number of data processing and analysing in future occupation career. For example, business management, financial, accounting professional students may need to use database online analytical tools for prediction and analysis. Class $\mathrm{C}$ of college students is also corresponding with non-computer professionals, and they only need to know basic knowledge of database technology and master information consumption basic skills. Of course, this kind of division is not absolute; in fact, the application of database technology has penetrated into almost all fields of college students' future employment. If college students can master higher level of database theory and application skill, they can adapt to their future jobs as soon as possible.

\section{B. Training System of Database Application Ability}

Generally speaking, application ability training of database technology for class A, B and C of college students are completed by different teaching units. And relevant theoretical knowledge and skills training is also decomposed into different courses teaching. For example, application ability training of database technology for class A professional students is implemented by Department of Computer Science. And application ability training of database technology for class B and C of professional students is implemented by Department of Computer Fundamental.

By using Computer Science and Technology, Network Engineering as example of class A professionals.
Computer Science and Technology specialty educates high-level technical talents who can work for computer application researching, teaching, developing, and managing in science departments, educational institutions, enterprises and administrative departments. A large number of basic concepts (e.g. data, information, information processing, etc.) are introduced in Professional Introduction. And database system theory and system development skills are strengthened in the following theory teaching and skill training courses. So, the solid foundation is established for working in database application system design, development and management.

Network Engineering specialty educates high-level technical talents who can work for network application software development, network engineering management, network security management in science departments, educational institutions, enterprises and administrative departments. A large number of basic concepts (e.g. data, information, information processing, etc.) are introduced in Professional Introduction. And network database theory and network application skills are strengthened in the following theory teaching and skill training courses. So, the solid foundation is established for working in network application hardware and software design, development and management.

For class $\mathrm{B}$ of non-computer specialty, University Computer Foundation trains information consumption skills of college students in information retrieval, processing, and transmission etc. Database Program Design trains students' database application thinking by using demand analysis, concept design, and software programming of information system example based on Visual FoxPro or C\# + Access.

For class $\mathrm{C}$ of non-computer specialty, the content of University Computer Foundation is different from class B. A large number of basic concepts (e.g. data, information, sort, statistics, keyword etc.) are introduced based on EXCEL software, and data processing skills is trained. Internet and Multimedia Technology trains information consumption skills of college students in information retrieval, processing, and transmission etc. So that students may gradually establish the application thinking of database technology.

\section{Practice in Ability Training of Database Application}

\section{A. Multi-layers configuring knowledge points}

In view of development of data management technology and emergence of new data processing technology, the knowledge points related to database technology may be divided into following 4-layers by using database application as main line[4][5].

(1) Base layer: Professional Introduction or University Computer Foundation are introductory courses for computer majors or non-computer majors learning computer basic knowledge. Basic concepts, EXCEL software and its application are presented in these courses, which provide students with basic knowledge for learning database.

(2) Initial layer: Program Design is a specialized compulsory basic course of class A and B. The course teaches high-level programming language, structured program thinking 
and object oriented program design. So, college students may master basic programming skills. Class A of college students mainly studies $C$ language programming technology or JAVA language programming technology. Class B of college students learns program design skills and database application skills at the same times based on Visual FoxPro or C\# + Access.

(3) Application layer: This layer is composed of Data Structure, Database Principle and other related courses. According to different training targets of computer professional talents, the teaching of database technology tends to differentiation. Data Structure course introduces storage structure and access mode of data, provides knowledge accumulation for learning two-dimensional table structure and physical storage model of database technology. Database Principle (or Network Database) course teaches basic theory, concept design, $S Q L$ language and database application in software system development.

(4) Enhanced layer: This layer includes Software Engineering, IS Development and Integration (IS-Information System) and other related courses. These courses teaches the design method and develop method of database application system, Web Application Development related to distributed database, database analysis and modelling, database performance testing, database management and data mining, etc. Different professionals can also choose other related new technologies for students to self-study according to their personal interest and future employment.

In the implementation of specific teaching, the knowledge points of database application also need to be configured according to the training plan of knowledge levels and different professionals. Theory knowledge and skills training program are scheduled to four years of teaching plan in accordance with necessarily specific order. For example, class $\mathrm{C}$ students only laid the base layer of database knowledge and the skills training of information consumption. Class B students need to configure base layer and initial layer of database knowledge, and a preliminary training of basic programming skills and information system development. According to their employment wishes, the knowledge of database system design, database management and application system development should be configured for class A of college students besides base layer and initial layer of database knowledge.

Therefore, according to the different train positioning of database application ability, through multi-layers configuring knowledge point (capacity point), reforming teaching contents and teaching methods as well as assessing methods, so that students can master a course (capacity surface) in different functions of training projects (capacity line). At the same time, through a series of courses learning, students can complete course system training of database application ability (capacity body). Practice has proved, by using point, line, surface, body of teaching mode, combining the reform of various teaching methods, the teaching effect can be greatly improved.

\section{B. Progressive training of database application ability}

The application ability cultivation of database technology for college students is a gradual process. After explaining necessary theoretical knowledge, teacher should develop students' ability to analyse and solve problems in the first. This is a process to fully understand knowledge, and runs through whole process of teaching courses of database. Secondly, teacher should cultivate students' practical ability via designing and developing someone database management system. When students have ability of analysing problem, solving problem and practical operation, teacher may guide students to selfstudy for training students' creative ability ${ }^{[6][7]}$.

\section{1) Developing students' analysis ability}

The target of database application teaching is to cultivate students' application ability of database technology; this requires students to use theoretical knowledge for analysing problems. For example, when learning $S Q L$ language, teacher may guide students to learn decomposing knowledge, and SELECT-SQL structure may be decomposed into several parts to understand. SELECT (What choose?) $\rightarrow$ FORM (Where from?) $\rightarrow I N T O$ (Where send?) $\rightarrow$ WHERE (What conditions?) $\rightarrow$ GROUP BY (How group?) $\rightarrow$ ORDER BY (What order?), etc. When someone data operation may be completed by different $S Q L$ statements, teacher should analyse each method, make students understand and master every method.

In the explanation of database design method, teacher should pay attention to methods introduction. For example, when designing a database, the key lies in entity analysis, attribute selection, entity relation determination, as well as field type, field width, etc. Through examples students may master basic method of database design. Due to different understanding of data processing needs, design results may be different. Teacher should guide students to analyse and compare different database structure combined with basic theory of database design, so as to determine reasonable design of database structure.

\section{2) Training students' practice ability}

The application ability cultivation of database technology is a practical training process; students can really and truly understand theoretical knowledge only through computer operation. In order to improve the quality of practical teaching, teacher should do a good job in the relationship between theory teaching and experiment teaching first of all, and make theoretical courses and experimental courses simultaneously, can not advance, and also cannot lag. For example, the total hours of Visual FoxPro Database Programming for class B of management majors is 64, and where 32 is lab hours. First 2 hours of 4 hours per week are theoretical courses, and then arrange 2 hours in computer room.

Secondly, teacher should let student clear and definite experimental purpose which requires teachers to prepare experimental instructions. The instructions should closely link to theoretical contents. For example, in order to train students' application ability of database technology in Foshan University, some teachers write two assorting textbooks of Visual FoxPro Database Programming and Exercises and Operation Guidance to Visual FoxPro Database 
Programming. In Feb. 2005 and Nov. 2008, two assorting textbooks issued first edition and second edition by Chinese Railway Publishing House. Two textbooks are used in many colleges, and get good effect for cultivating college students' application ability of database technology.

Before experiment, students should preview experimental instructions. In experiment, teacher should do good guidance. After experiment, experimental results must be given to teacher in order to understand student's practice. Experiment report may include experimental experience and harvest.

\section{Ability training by university-enterprise cooperation}

University and enterprise all are the core of cooperatively training application talents of database technology. Enterprise hopes university train qualified personnel, as far as possible to reduce enterprise's training costs. Application talents training of database technology via university-enterprise cooperation can take one of following two modes ${ }^{[8]}$.

Mode 1: University-enterprise cooperation builds a training base conjunctively. The base is responsible for relevant theory knowledge teaching and development skills training of information system. Training base may be established in university, and managed by university. Teaching plan may be undertaken by university and enterprise jointly, or by third party training institutions invited.

Mode 2: University and enterprise educate talents jointly. University is responsible for teaching theory knowledge of database technology in Grade $1 \sim$ Grade 3, enterprise is responsible for training application skills of database technology in Grade 4 via information system development. University and enterprise assigned respectively an advisor for supervision and guidance of students' skill training process. $" 3+1 "$ training mode may enable students to work in advance, and meet enterprise's talent need.

Foshan University is one of local undergraduate universities, training applied talents for Foshan City and Guangdong Province is main task and target. Therefore, in order to train application talents of database technology, "3+1" personnel training mode is explored. In Grade 1 Grade 3, Class A of computer professional students complete theory basis education and basic skills training in university. In the end of sixth semester, students selection into " $3+1 "$ training mode is fulfilled via student-enterprise two-way choice. After parents confirmed, enterprise and university assigned advisors, and enterprise purchased commercial insurance, students may enter enterprise for application ability training. University and enterprise often communicate for tracking students' training trajectory, urging students to finish following graduation design link. For students failed to enter " $3+1$ " training mode, teacher may guide them to complete information system development training and following graduation design link in university via project driven approach.

\section{Conclusion}

With constant extension of database applications fields, in order to cultivate high-skilled applicable talents with actual working zero distance, we must renew education ideas, optimize teaching content, improve teaching means for constructing a scientific, reasonable teaching mode and assessing method.

In the teaching process of database application courses, students need to master certain theoretical knowledge in the first. At the same times, teachers should guide students to train analysing problem ability, solving problem ability, practical ability, and creative thinking ability. Through some practical training project, students' application skills are gradually cultivated; a solid foundation is established for students' future study and work.

In addition, the construction of teacher team and teaching materials should be continued to strengthen. Via improving teaching resources and enhancing external training base, curriculum teaching system of database application are more adaptive and keep in step with society development.

\section{References}

[1] Zhen Zhu, Jing-yan Wang, Xiao-sheng Hu, Yan-chun Gu. Modeling and Analyzing of Informationalized Consumption Behavior. Proceedings of 2013 the 6th International Conference on Information Management, Innovation Management and Industrial Engineering, Nov. 2013

[2] Jing-yan Wang, Zhen Zhu, Qiu-ming Lin. System Constitution and Method Innovation of Information Literacy Training for University Students. Proceedings of 2013 the 3rd International Conference on Applied Social Science, Jan. 2013

[3] Jeannette M. Wing. Computational Thinking. Communication of the ACM, Vol.49, No.3, March 2006

[4] Jia-ling Liu, Xin Feng, Jing Yin. Teaching System Construction of Database Technology for IT Specialty in Local College. Journal of Chongqing University of Technology (Social Science), Vol.27, No.6, June 2013

[5] Yan Pan. Reform And Implementation of Database Application Curriculum System in Higher Vocational Schools. Liaoning Higher Vocational Technological Institute Journal, Vol.13, No.5, May 2011

[6] Yan Ren. Discussion on the Curriculum Reform Based on Working Process Systematization. Journal of Changchun Education Institute, Vol.29, No.21, Nov.2013

[7] Xiao-bing Chen, You-dong Zhang. Progressive Teaching Method for Cultivating College Students' Ability of Database Application. China Science and Technology Information, Vol.2006, No.14. July 2006

[8] Ying-long Ge, Xiao-jun Gong, Zheng-qian Xu. A Probe into Tradeoriented Database Personnel Training with Application Competence. Journal of Hangzhou Dianzi University (Social Sciences), Vol.7, No.3, Sep. 2011 